Article

\title{
Effect of Cr, Mo and Al on Microstructure, Abrasive Wear and Corrosion Resistance of Ni-Mn-Cu Cast Iron
}

\author{
Daniel Medyński ${ }^{1, *}$, Bartłomiej Samociuk ${ }^{2}$, Andrzej Janus ${ }^{2}$ and Jacek Chęcmanowski ${ }^{3}$ \\ 1 Faculty of Technical and Economic Sciences, Witelon State University of Applied Science in Legnica, \\ Sejmowa 5A, 59-220 Legnica, Poland \\ 2 Department of Foundry Engineering, Plastics and Automation, Wroclaw University of Technology, \\ Smoluchowskiego 25, 50-372 Wroclaw, Poland; bartlomiej.samociuk@pwr.edu.pl (B.S.); \\ andrzej.janus@pwr.edu.pl (A.J.) \\ 3 Department of Advanced Materials Technologies, Wroclaw University of Technology, Smoluchowskiego 25, \\ 50-372 Wroclaw, Poland; jacek.checmanowski@pwr.edu.pl \\ * Correspondence: d.medynski.pwsz@interia.pl
}

Received: 5 August 2019; Accepted: 23 October 2019; Published: 25 October 2019

\begin{abstract}
Results of a study on influence of $\mathrm{Cr}$, Mo and $\mathrm{Al}$ on the microstructure, abrasive wear and corrosion resistance of Ni-Mn-Cu cast iron in the as-cast and heat-treated conditions are presented. Because of the chilling effect of first two elements (tendency to create hard spots), graphitising $\mathrm{Al}$ was added to the alloys, with the highest concentration of $\mathrm{Cr}$ and Mo. All castings in the as-cast condition showed an austenitic matrix, guaranteeing good machinability. Heat treatment of raw castings, consisting in annealing at $500{ }^{\circ} \mathrm{C}$ for $4 \mathrm{~h}$, resulted in partial transformation of austenite. As a result the carbon-supersaturated acicular ferrite, morphologically similar to bainitic ferrite was formed. The degree of this transformation increased with increasing concentrations of $\mathrm{Cr}$ and Mo, which successively decreased the thermodynamic stability of austenite. A change of matrix structure made it possible to significantly increase hardness and abrasive-wear resistance of castings. The largest increment of hardness and abrasion resistance was demonstrated by the castings with the highest total concentration of $\mathrm{Cr}$ and Mo with an addition of $0.4 \% \mathrm{Al}$. Introduction of $\mathrm{Cr}$ and Mo also resulted in an increase of corrosion resistance. In the heat-treated specimens, increasing the concentration of $\mathrm{Cr}$ and Mo resulted in a successive decrease of the depth of corrosion pits, with an increase in their number at the same time. This is very favourable from the viewpoint of corrosion resistance.
\end{abstract}

Keywords: abrasive wear; austenitic cast iron; austenitic transformation; corrosion resistance; $\mathrm{Ni}-\mathrm{Mn}-\mathrm{Cu}$ cast iron

\section{Introduction}

A typical example of cast iron with relatively good machinability and corrosion resistance is $\mathrm{Ni}$-Resist austenitic cast iron [1,2]. However, this is a material with low abrasion resistance. The alternative is Ni-Mn-Cu cast iron with a radically reduced $\mathrm{Ni}$ content compared to Ni-Resist cast iron, wherain the reduced $\mathrm{Ni}$ content is compensated by the addition of austenitizing elements, such as $\mathrm{Mn}$ and $\mathrm{Cu}[2]$.

Proper selection of chemical composition of the Ni-Mn-Cu cast iron makes it possible to obtain castings with an austenitic structure, guaranteeing good machinability [2]. In turn, proper selection of heat treatment parameters, provoking radical changes on the casting matrix, which makes it possible to obtain good mechanical properties and high abrasive-wear resistance while maintaining increased corrosion resistance (high electrochemical potential of the alloying elements) [3-8]. This makes it 
possible to use this type of cast iron to cast machine parts working under hard conditions such as those encountered in the mining industry.

Selection of chemical composition is mainly based on value of nickel equivalent $\mathrm{Equ}_{\mathrm{Ni}}$, which indicates the thermodynamic stability of the austenitic matrix. If the equivalent value calculated according to Equation (1) [9] is smaller than 16.0\%, it results in partial transformation of austenite to acicular ferrite $[4,5,8,9]$.

$$
\mathrm{Equ}_{\mathrm{Ni}}=0.32 \cdot \mathrm{C}+0.13 \cdot \mathrm{Si}+\mathrm{Ni}+2.48 \cdot \mathrm{Mn}+0.53 \cdot \mathrm{Cu}
$$

where $\mathrm{Equ}_{\mathrm{Ni}}$-nickel equivalent [wt \%], $\mathrm{C}, \mathrm{Si}, \mathrm{Ni}, \mathrm{Mn}, \mathrm{Cu}$ —concentrations of elements [wt \%].

The higher the degree of this transformation is, the smaller the nickel equivalent value $[4,5,8]$. This leads to significantly higher hardness of the castings, which considerably impedes their mechanical working.

In turn, if the $\mathrm{Equ}_{\mathrm{Ni}}$ value is at least $16.0 \%$, the matrix structure of raw castings is composed exclusively of austenite [9]. An increase of the equivalent value results in increased stability of the austenitic matrix $[8,10]$. This is a favourable phenomenon from the viewpoint of the possibility to obtain a structure durable in a wide range of temperatures. However, this restricts the possibility to obtain, by heat treatment, a hard and abrasion resistant structure, with respect to the properties similar to those of the austempered ductile (ADI) cast iron [11-25].

In this respect, it is most advantageous to use a cast iron with the $\mathrm{Equ}_{\mathrm{Ni}}$ value of ca. $16.0 \%$. This allows one to obtain raw castings with an austenitic matrix and to change this structure by a technically simple heat treatment (soaking and air-cooling) [6,7].

It seems possible to increase hardness, abrasive-wear resistance and corrosion resistance of $\mathrm{Ni}-\mathrm{Mn}-\mathrm{Cu}$ cast iron by introducing chromium and molybdenum, the elements commonly used to this end in other grades of cast iron. Due to the chilling effect of these elements, it seems reasonable to add, at the same time, a small amount of aluminium. Therefore, the purpose of the work was to determine to what extent additions of $\mathrm{Cr}$, Mo and $\mathrm{Al}$ will affect the structure, hardness, abrasive-wear resistance and corrosion resistance of heat-treated castings.

\section{Materials and Methods}

Examinations were carried-out on cast iron coming from nine melts (Table 1). At the assumed constant concentration of basic elements: $3.4 \pm 0.2 \% \mathrm{C} ; 1.8 \pm 0.2 \% \mathrm{Si} ; 4.2 \pm 0.2 \% \mathrm{Mn} ; 3.2 \pm 0.2 \% \mathrm{Ni}$; $1.8 \pm 0.2 \% \mathrm{Cu} ; 0.18 \pm 0.2 \% \mathrm{P}$ and $0.01 \% \mathrm{~S}$, the concentrations of $\mathrm{Cr}$ and Mo were changed from 0.4 to $1.8 \%$ and from 0.2 to $0.5 \%$, respectively. Moreover, an addition of $0.4 \% \mathrm{Al}$ was applied in the alloys with higher concentrations of $\mathrm{Cr}$ and $\mathrm{Mo}$, in order to compensate their chilling effect (tendency to create hard spots). Such a selection of chemical composition, developed on the basis of previous studies and literature data [26], should make it possible to obtain nearly-eutectic cast iron with low thermodynamic stability of the austenitic matrix of raw castings, and with limited tendency to create hard spots.

Table 1. Chemical composition of raw casts, nickel equivalent $\mathrm{Equ}_{\mathrm{Ni}}$ and eutectic saturation ratio $\mathrm{S}_{\mathrm{C}}$.

\begin{tabular}{|c|c|c|c|c|c|c|c|c|c|c|c|c|}
\hline \multirow{2}{*}{$\begin{array}{c}\text { Alloy } \\
\text { No. }\end{array}$} & \multicolumn{10}{|c|}{ Chemical Composition [wt \%] } & \multirow{2}{*}{$\begin{array}{l}\mathrm{S}_{\mathrm{C}} \\
{[/]}\end{array}$} & \multirow{2}{*}{$\begin{array}{c}\mathrm{Equ}_{\mathrm{Ni}} \\
{[\mathrm{wt} \%]}\end{array}$} \\
\hline & $\mathrm{C}$ & Si & Mn & $\mathrm{Ni}$ & $\mathrm{Cu}$ & $\mathrm{Cr}$ & Mo & Al & $\mathbf{P}$ & $S$ & & \\
\hline 1 & 3.5 & 1.9 & 4.3 & 3.3 & 1.9 & - & - & - & 0.19 & 0.01 & 1.02 & 16.3 \\
\hline 2 & 3.6 & 1.8 & 4.2 & 3.2 & 2.0 & 0.4 & - & - & 0.19 & 0.01 & 1.03 & 16.1 \\
\hline 3 & 3.4 & 1.7 & 4.4 & 2.9 & 1.7 & 0.7 & - & - & 0.20 & 0.01 & 0.95 & 16.0 \\
\hline 4 & 3.5 & 1.8 & 4.2 & 3.4 & 1.8 & 0.9 & - & 0.4 & 0.18 & 0.01 & 1.02 & 16.1 \\
\hline 5 & 3.4 & 2.0 & 4.1 & 3.4 & 2.0 & 1.8 & - & 0.4 & 0.17 & 0.01 & 0.99 & 16.0 \\
\hline 6 & 3.4 & 2.0 & 4.3 & 3.3 & 1.7 & 0.7 & 0.2 & - & 0.18 & 0.01 & 0.97 & 16.2 \\
\hline 7 & 3.6 & 1.9 & 4.3 & 3.1 & 1.8 & 1.0 & 0.2 & - & 0.16 & 0.01 & 1.01 & 16.1 \\
\hline 8 & 3.3 & 1.7 & 4.2 & 3.3 & 1.9 & 0.7 & 0.5 & 0.4 & 0.20 & 0.01 & 0.95 & 16.0 \\
\hline 9 & 3.5 & 1.8 & 4.2 & 3.2 & 2.0 & 1.1 & 0.5 & 0.4 & 0.18 & 0.01 & 1.01 & 16.0 \\
\hline
\end{tabular}


The cast iron was melted in an induction medium-frequency furnace, in a type $\mathrm{A} 35 \mathrm{SiC}$ crucible. Castings of alloys from 1 to 9 in the form of dia. $30 \mathrm{~mm} \times 250 \mathrm{~mm}$ shafts were cast in shell moulds. Then, each of the obtained casts was cut into test samples in the form of $10 \mathrm{~mm}$ thick rollers, which were subjected to metallographic tests. Raw cast iron samples and after heat treatment were tested. Heat treatment of samples consisted in soaking at $500^{\circ} \mathrm{C}$ for $4 \mathrm{~h}$ (in a resistance furnace), followed by air cooling.

From the obtained castings, specimens were taken for chemical analysis, microscopic observations, hardness measurements, abrasive-wear resistance tests and corrosion resistance tests. All research results are average values from at least three measurements.

Chemical analysis was carried-out spectrally with use of a GDS 750 QDP glow discharge analyser (Leco, London, UK) and Quanta 250 scanning electron microscope (FEI, Waltham, MA, USA) equipped with an EDS detector. Results of the analysis, as well as values of nickel equivalent $\mathrm{Equ}_{\mathrm{Ni}}$ (calculated according to the equation (1)) and of eutectic saturation ratio $S_{C}$ (indicator of degree of deviation in the chemical composition of cast iron from its eutectic composition) are given in Table 1.

Microscopic examinations were performed using a MA200 light microscope (Nikon, Bangkok, Thailand) and TM 3000 (Hitachi, Tokyo, Japan) and FEI Quanta 250 scanning electron microscopes.

Brinell hardness was measured acc. to EN ISO 6506-1:2014-12 on an Nexus tester (Innovatest, Maastricht, Netherlands) with a ball dia. $2.5 \mathrm{~mm}$ under $1838.75 \mathrm{~N}$. Vickers microhardness was measured acc. to EN ISO 6507-1:2018-05 on an Nova tester by Innovatest (Innovatest, Maastricht, Netherlands) under the indenter load of $0.01 \mathrm{~N}$ and $0.1 \mathrm{~N}$.

Abrasive-wear resistance was determined by the "pin-on-disc" method on machine (Struers, Tokyo, Japan). Measurements consisted in abrading specimens dia. $25 \mathrm{~mm}$ pressed at $30 \mathrm{~N}$ against a diamond disk (grain size 45 to $53 \mu \mathrm{m}$ ) cooled with water. The measurements were performed in six cycles. Each cycle lasting $5 \mathrm{~min}$ corresponded to the sliding distance of $175 \mathrm{~m}$. Therefore, each specimen was abraded for $30 \mathrm{~min}$ on the distance of $1050 \mathrm{~m}$.

Corrosion resistance of the alloy was determined using the gravimetric and the potentiodynamic methods. In both cases, 3-\% water solution of $\mathrm{NaCl}$ was used as the corrosive solution, at ambient temperature [27]. During gravimetric measurements, the corrosive medium was aerated in order to increase its aggressiveness [28].

Results of gravimetric tests are presented as mass loss per unit of time per unit area of the specimen $V_{C}\left[\mathrm{mg} /\left(\mathrm{dm}^{2} \cdot\right.\right.$ day $\left.)\right]$ and, after conversion by the formula $(2)[29,30]$, as linear corrosion rate $V_{\mathrm{P}}$ :

$$
\mathrm{V}_{\mathrm{P}}=\left(0.0365 \cdot \mathrm{V}_{\mathrm{C}}\right) / \mathrm{d}
$$

where $\mathrm{V}_{\mathrm{P}}$-linear corrosion rate $[\mathrm{mm} / \mathrm{year}], \mathrm{V}_{\mathrm{C}}$-mass loss of the specimen in time $\left[\mathrm{mg} /\left(\mathrm{dm}^{2} \cdot \mathrm{day}\right)\right]$, $\mathrm{d}$-density of the metallic material $\left[\mathrm{g} / \mathrm{cm}^{3}\right]$.

Potentiodynamic measurements were carried-out in a completely automated three-electrode system, using a potentiostat (BioLogic, Seyssinet-Pariset, France). A saturated calomel electrode was used as the reference electrode. The auxiliary electrode was a platinum electrode [31-33]. Polarisation of all specimens was started from the potential of ca. $-900 \mathrm{mV}_{\mathrm{NEC}}$, at $1 \mathrm{mV} / \mathrm{s}$ in the anodic direction. Corrosion resistance was determined on the grounds of cathodic-anodic transition potential $\mathrm{E}_{\mathrm{K}-\mathrm{A}}$, stationary potential $\mathrm{E}^{\prime}$, corrosion current density $\mathrm{i}_{\text {corr }}$ and polarisation resistance $\mathrm{R}_{\mathrm{P}}$.

\section{Results and Discussion}

\subsection{Microscopic Observations and Hardness Measurements of Raw Castings}

Microscopic observations, including determination of graphite features acc. to EN ISO 945-1:2018-04, were carried-out on polished sections unetched and etched with Nital, see Figure 1. Results of qualitative analysis of microstructure are given in Table 2. 
Table 2. Composition of microstructure and hardness of raw castings.

\begin{tabular}{|c|c|c|c|c|c|}
\hline $\begin{array}{c}\text { Alloy } \\
\text { No. }\end{array}$ & $\begin{array}{l}\mathrm{Equ}_{\mathrm{Ni}} \\
{[\mathbf{w t} \%]}\end{array}$ & Matrix & $\begin{array}{l}\text { High-Carbon Phases } \\
\% \mathrm{Fe}_{3} \mathrm{C}-\mathrm{oC}_{\mathrm{gr}}{ }^{*} \\
\text { /type of } \mathrm{C}_{\mathrm{gr}} /\end{array}$ & $\begin{array}{c}\text { HBS }_{\text {AVR }} \\
2.5 / 187.5 \mathrm{kG} \\
{[/]} \\
(+/-2)\end{array}$ & $\begin{array}{c}\text { HV0.01N } \mathrm{NVR}_{\mathrm{AVR}} \\
\text { of Austenite } \\
{[/]} \\
(+/-2)\end{array}$ \\
\hline 1 & 16.3 & austenite & $0 \% \mathrm{Fe}_{3} \mathrm{C}-100 \% \mathrm{C}_{\mathrm{gr}} / \mathrm{IA} 4 /$ & 160 & 168 \\
\hline 2 & 16.1 & austenite & $0 \% \mathrm{Fe}_{3} \mathrm{C}-100 \% \mathrm{C}_{\mathrm{gr}} / \mathrm{IE} 4 /$ & 170 & 182 \\
\hline 3 & 16.0 & austenite & $0 \% \mathrm{Fe}_{3} \mathrm{C}-100 \% \mathrm{C}_{\mathrm{gr}} / \mathrm{IE} 4 /$ & 185 & 192 \\
\hline 4 & 16.1 & austenite & $10 \% \mathrm{Fe}_{3} \mathrm{C}-90 \% \mathrm{C}_{\mathrm{gr}} / \mathrm{IE} 5 /$ & 280 & 204 \\
\hline 5 & 16.0 & austenite & $95 \% \mathrm{Fe}_{3} \mathrm{C}-5 \% \mathrm{C}_{\mathrm{gr}} / \mathrm{IE} 6 /$ & 380 & 230 \\
\hline 6 & 16.2 & austenite & $45 \% \mathrm{Fe}_{3} \mathrm{C}-55 \% \mathrm{Cgr}_{\mathrm{gr}} / \mathrm{ID} 5 /$ & 205 & 195 \\
\hline 7 & 16.1 & austenite & $50 \% \mathrm{Fe}_{3} \mathrm{C}-50 \% \mathrm{C}_{\mathrm{gr}} / \mathrm{ID} 5 /$ & 220 & 203 \\
\hline 8 & 16.0 & austenite & $55 \% \mathrm{Fe}_{3} \mathrm{C}-45 \% \mathrm{C}_{\mathrm{gr}} / \mathrm{ID} 5 /$ & 210 & 214 \\
\hline 9 & 16.0 & austenite & $60 \% \mathrm{Fe}_{3} \mathrm{C}-40 \% \mathrm{C}_{\mathrm{gr}} / \mathrm{ID} 4 /$ & 250 & 207 \\
\hline
\end{tabular}

${ }^{*} \mathrm{Fe}_{3} \mathrm{C}$-cementite; $\mathrm{C}_{\mathrm{gr}}$-graphite; $\mathrm{Fe}_{3} \mathrm{C}+\mathrm{C}_{\mathrm{gr}}=100 \%$ high-carbon phases.

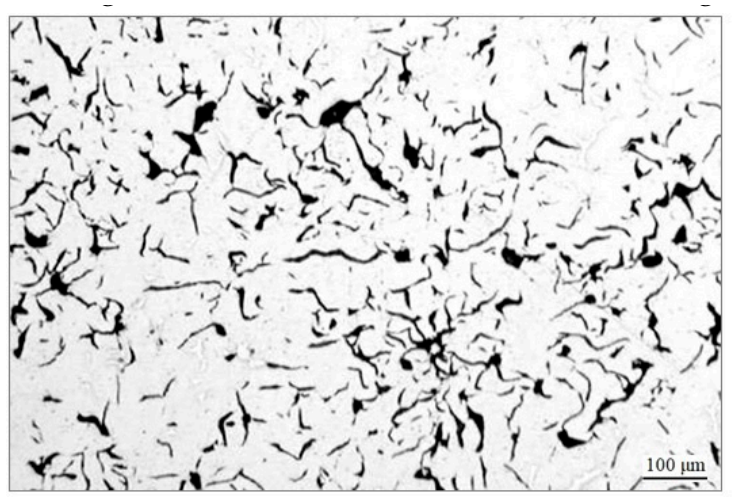

(a)

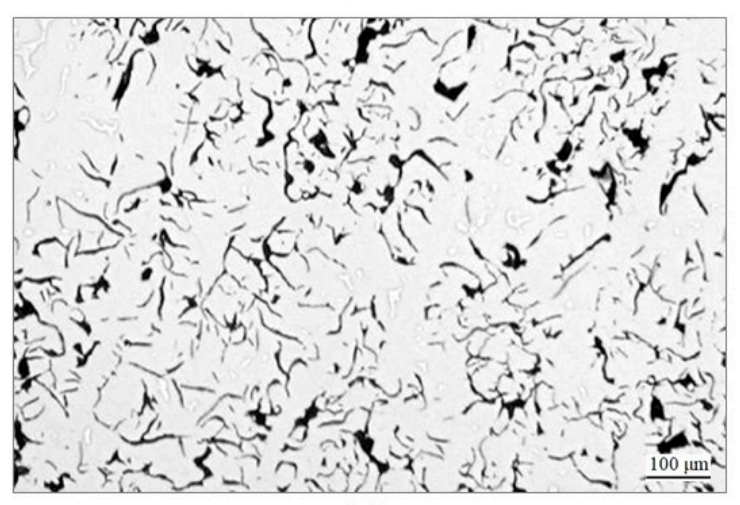

(c)

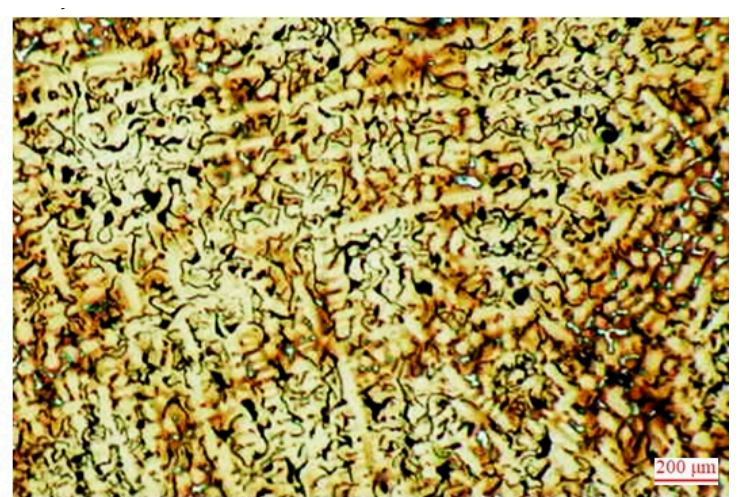

(b)

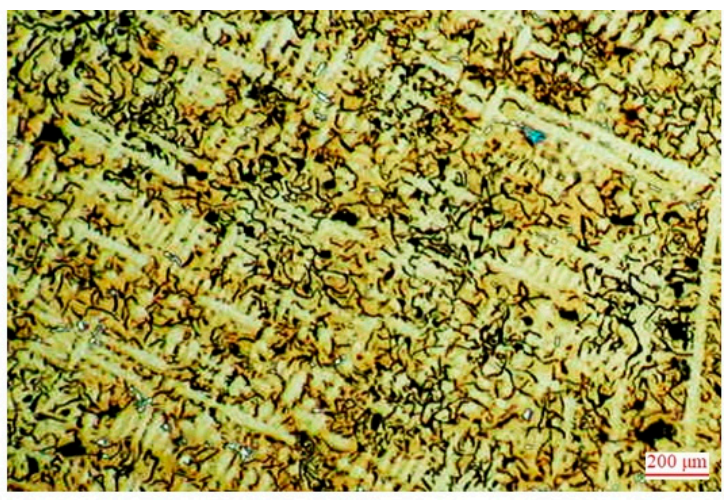

(d)

Figure 1. Cont. 


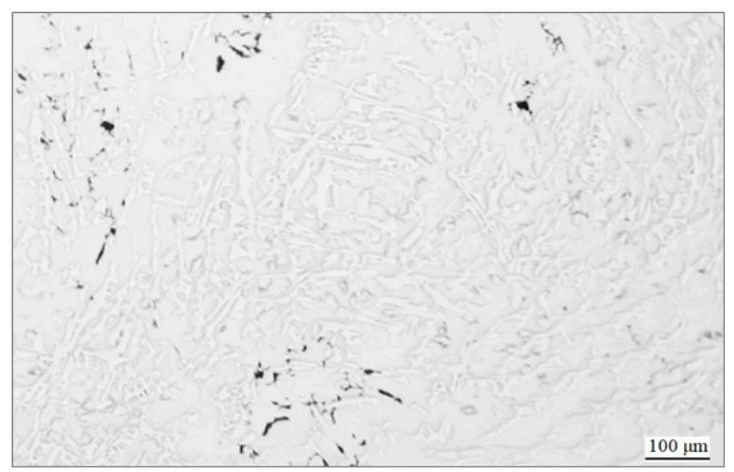

(e)

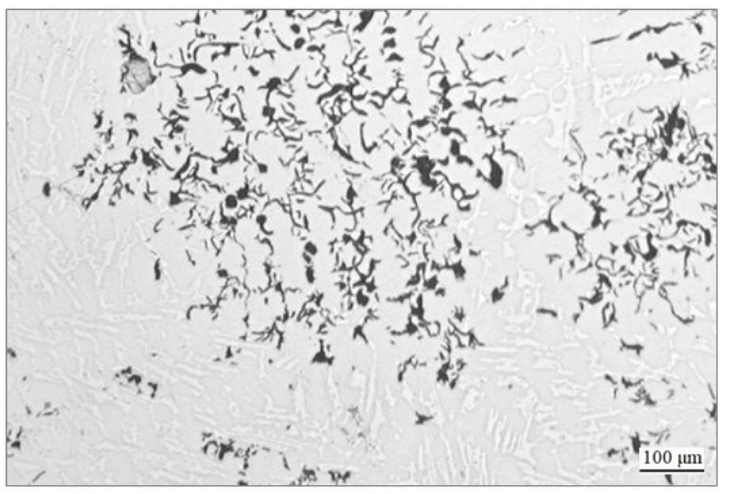

(g)

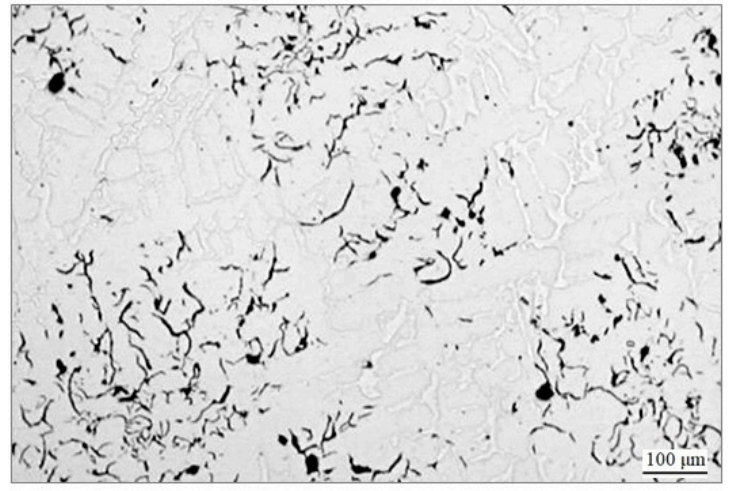

(i)

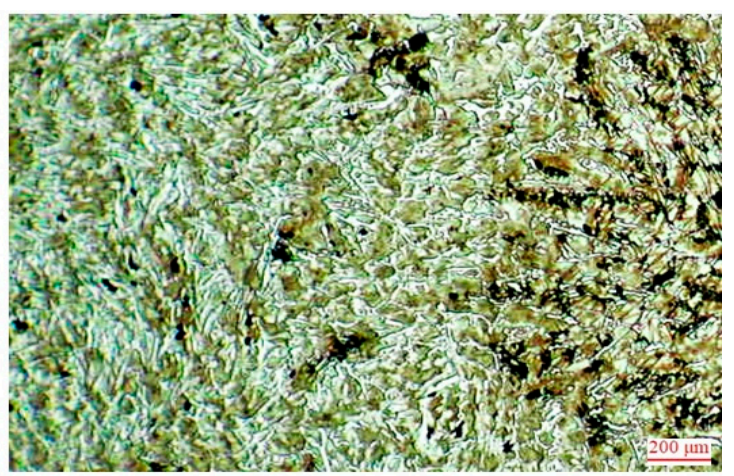

(f)

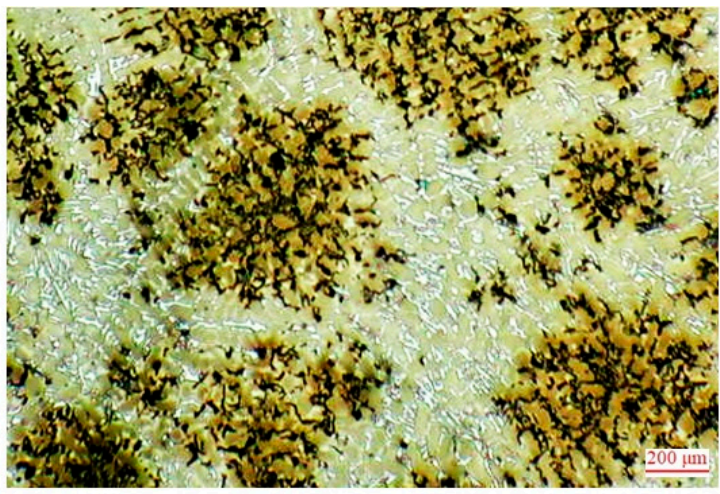

(h)

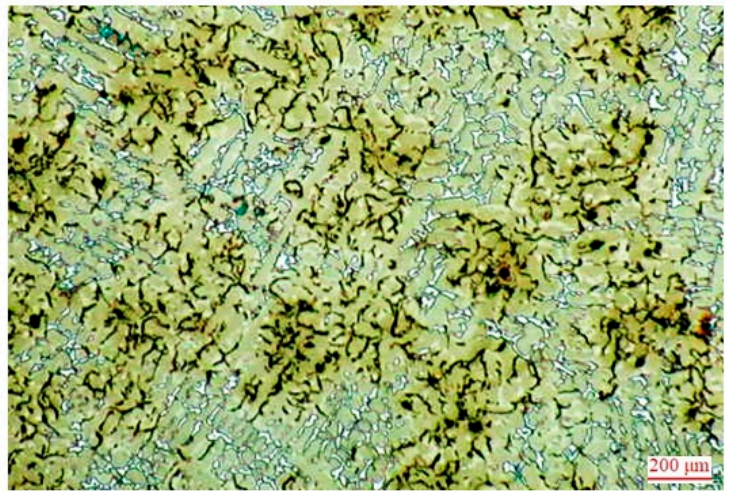

(j)

Figure 1. Microstructures of raw castings: (a) No. 1-graphite IA4; (b) No. 1-austenite, graphite; (c) No. 2-graphite IE4; (d)No. 2-austenite, graphite; (e) No. 5-graphite IE6; (f) No. 5-austenite, graphite, cementite; (g) No. 8-graphite ID5; (h) No. 8-austenite, graphite, cementite; (i) No. 9-graphite ID4; (j) No. 9-austenite, graphite, cementite. Polished sections on the left unetched; those on the right etched with Nital.

Introduction of additional elements to Ni-Mn-Cu cast iron did not affect matrix structures of raw castings. In each case, the matrix was composed exclusively of austenite, see Figure $1 b, d, f, h, j$. However, features and quantities of graphite varied, see Figure 1a,c,e,g,i.

In the alloy No. 1 (with no addition of $\mathrm{Cr}$ and Mo), straight graphite type A size 4 was found, see Figure 1a. Introduction of $0.4 \% \mathrm{Cr}$ to the alloy No. 2 resulted in a reduction of quantity and size of graphite particles. A tendency for interdendritic type E arrangement appeared, see Figure 1c. These tendencies increased along with increasing chromium concentration in successive alloys No. 3 to 5. Beginning from $0.9 \% \mathrm{Cr}$ (the alloy No. 4 and next the alloy No. 5), in spite of introducing $0.4 \%$ $\mathrm{Al}$, partial chilling appeared in the castings, see Figure 1f. An addition of molybdenum, like that of 
chromium, resulted in smaller quantity and size of graphite particles, and increased the inclination for chilling. However, this effect was less intensive than the influence of chromium. In consequence, the highest degree of chilling was found in the alloy No. 5 (the highest content of $\mathrm{Cr}$ ) and No. 9 with the largest total content of both elements, see Figure $1 \mathrm{f}, \mathrm{j}$.

Introduction of additional elements and the related changes of microstructure resulted in changed HB hardness of the castings. The main factor deciding the hardness of raw castings was their chilling degree, strictly related to their total content of $\mathrm{Cr}$ and Mo. With increasing concentrations of these elements, the hardness of the alloys increased. A role was also played by HV hardness of austenite, which rose with increasing concentration of chromium: from $160 \mathrm{HV} 0.01 \mathrm{~N}$ in the Cr-free alloy No. 1 to $230 \mathrm{HV} 0.01 \mathrm{~N}$ in the alloy No. 5 with the highest concentration of $\mathrm{Cr}$. In consequence, the lowest hardness (160 HBS) was demonstrated by the Cr-free alloy No. 1, and the highest hardness (380 HBS)_by the Al-free alloy No. 5 containing $1.8 \%$ Cr.

\subsection{Microscopic Observations and Hardness Measurements of Heat-Treated Castings}

Heat treatment (soaking at $500{ }^{\circ} \mathrm{C}$ for $4 \mathrm{~h}$ followed by air cooling) resulted in changes of matrix structures of all the castings. Austenite was partially transformed to acicular ferrite, morphologically comparable with ferrite present in upper bainite. The transformation degree was different in individual castings, see Figure 2 and Table 3.

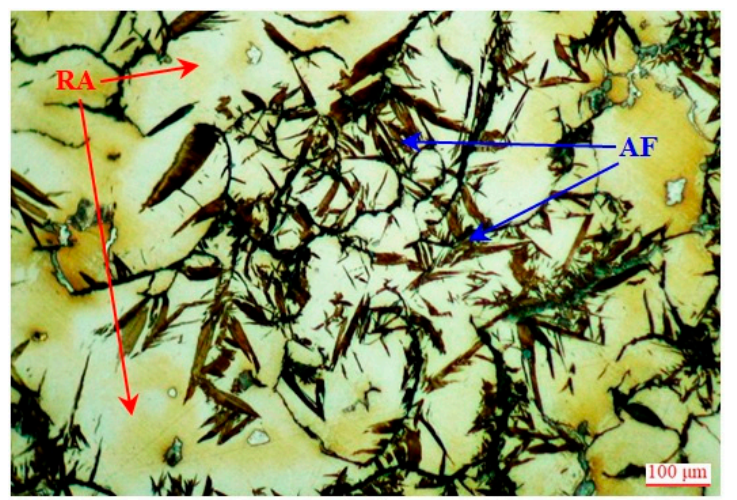

(a)

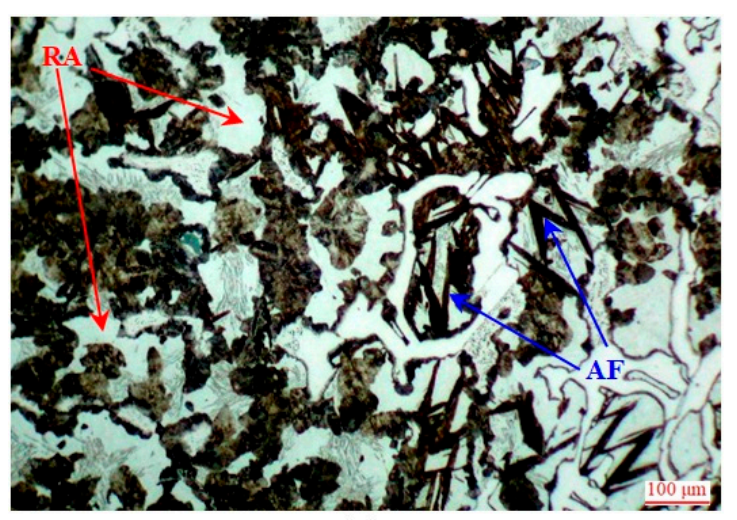

(c)

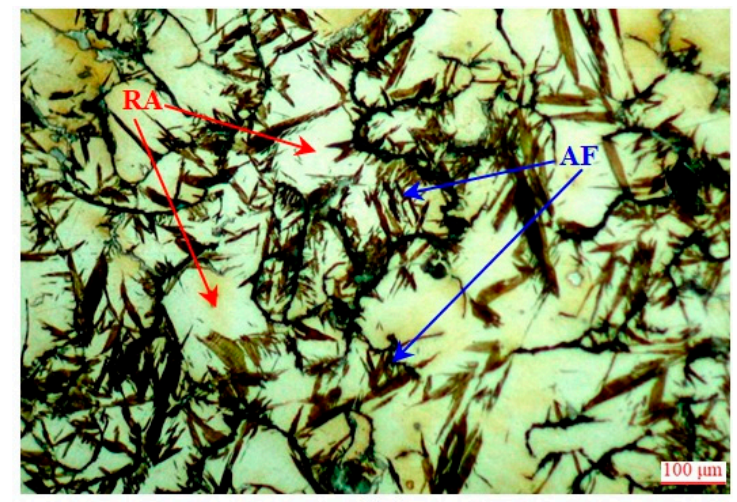

(b)

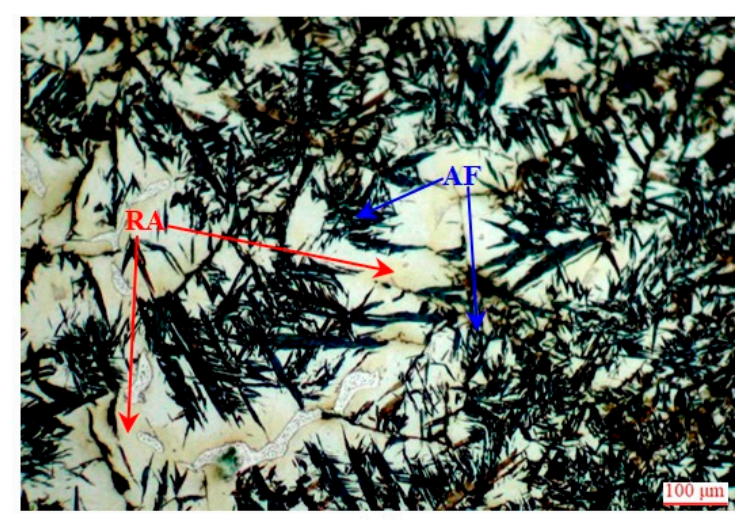

(d)

Figure 2. Cont. 


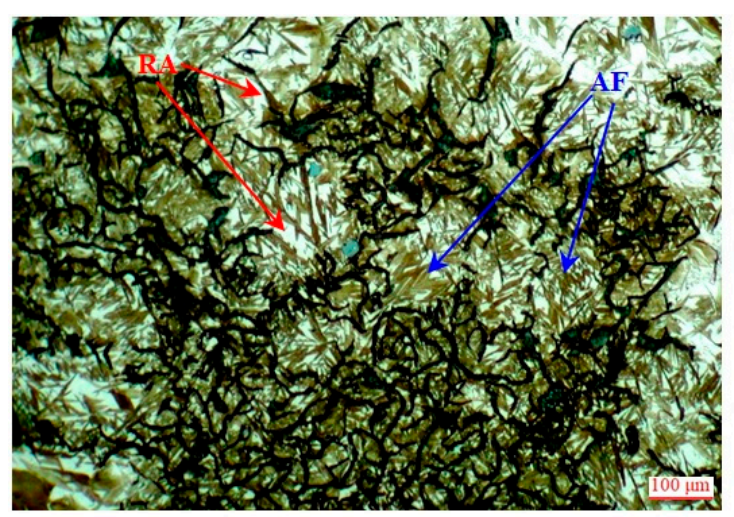

(e)

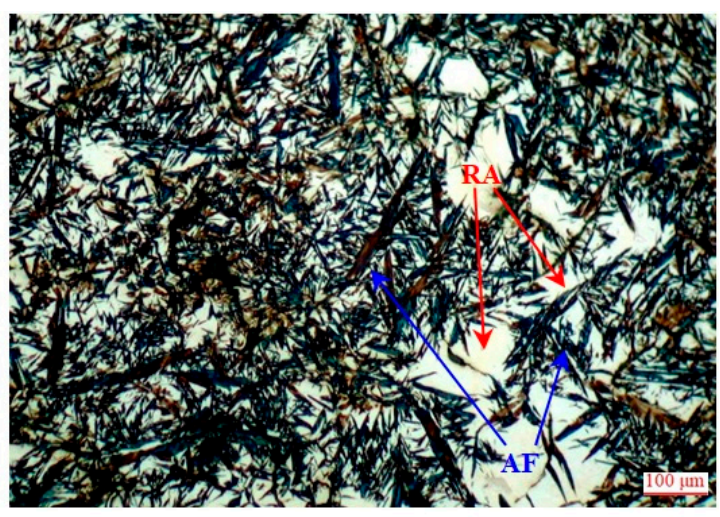

(f)

Figure 2. Microstructures of castings after heat treatment: (a) No. 1-retained austenite, acicular ferrite; (b) No. 2-retained austenite, acicular ferrite; (c) No. 5-retained austenite, acicular ferrite, pearlite; (d) No. 7- retained austenite, acicular ferrite; (e) No. 8-retained austenite, acicular ferrite; (f) No. 8 -retained austenite, acicular ferrite. Etched with Nital. RA-retained austenite; AF-acicular ferrite.

Table 3. Composition of microstructure and hardness for heat-treated castings.

\begin{tabular}{|c|c|c|c|c|c|}
\hline $\begin{array}{l}\text { Alloy } \\
\text { No. }\end{array}$ & $\begin{array}{c}\mathrm{Equ}_{\mathrm{Ni}} \\
{[\mathbf{w t} \%]}\end{array}$ & $\begin{array}{c}\text { Matrix } \\
\text { Components * } \\
\mathrm{A}-\mathrm{Fe}_{\mathrm{m}}-\mathbf{P} \\
{[\%-\%-\%]}\end{array}$ & $\begin{array}{c}\text { Form of Carbon } \\
\text { in Eutectic } \\
\text { Mixture } * *\end{array}$ & $\begin{array}{c}\mathrm{HBW}_{\text {AVR }} \\
2.5 / 187.5 \\
{[/]} \\
(+/-3)\end{array}$ & $\begin{array}{c}\text { Increase } \\
\text { of HBW } \\
2.5 / 187.5 \\
\text { [/] }\end{array}$ \\
\hline 1 & 16.3 & $50-50-0$ & $\mathrm{C}_{\mathrm{gr}}$ & 313 & 154 \\
\hline 2 & 16.1 & $48-52-0$ & $\mathrm{C}_{\mathrm{gr}}^{0}$ & 347 & 178 \\
\hline 3 & 16.0 & $47-53-0$ & $C_{g r}^{g^{2}}$ & 372 & 189 \\
\hline 4 & 16.1 & $45-55-0$ & $\mathrm{C}_{\mathrm{gr}+}+\mathrm{Fe}_{3} \mathrm{C}$ & 411 & 129 \\
\hline 5 & 16.0 & $45-25-30$ & $\mathrm{C}_{\mathrm{gr}+}+\mathrm{Fe}_{3} \mathrm{C}$ & 492 & 112 \\
\hline 6 & 16.2 & $45-55-0$ & $\mathrm{C}_{\mathrm{gr}}+\mathrm{Fe}_{3} \mathrm{C}$ & 362 & 157 \\
\hline 7 & 16.1 & $40-60-0$ & $\mathrm{C}_{\mathrm{gr}+\mathrm{Fe}_{3} \mathrm{C}}$ & 383 & 163 \\
\hline 8 & 16.0 & $10-90-0$ & $\mathrm{C}_{\mathrm{gr}+}+\mathrm{Fe}_{3} \mathrm{C}$ & 441 & 230 \\
\hline 9 & 16.0 & $15-85-0$ & $\mathrm{C}_{\mathrm{gr}}+\mathrm{Fe}_{3} \mathrm{C}$ & 454 & 205 \\
\hline
\end{tabular}

The smallest changes occurred in the alloy No. 1 (with no $\mathrm{Cr}$ and Mo). The austenite transformation degree did not exceed 50\%. Introducing and increasing concentrations of $\mathrm{Cr}$ and Mo successively increased this transformation degree. In the alloys No. 8 and No. 9 with the highest total concentration of both elements, from 85 to $90 \%$ of austenite underwent the transformation. This means that introduction of these elements reduced the thermodynamic stability of austenite.

Changes of matrix structure were accompanied by significant changes of hardness. Differences of hardness between individual castings were considered from two points of view: first-absolute hardness and second-hardness increment caused by heat treatment.

The lowest hardness (313 HBW) was found for the alloy No. 1 with the lowest austenite transformation degree. Higher hardness of the other alloys resulted from their increased inclination to chilling and/or increased degree of austenite transformation. Among the alloys with similar initial structure, i.e., the alloys No. 2,3 and No. 6, 7 higher hardness after heat treatment was demonstrated by the castings with higher concentrations of chromium. The highest hardness (492 HBW) was obtained for the alloy No. 5 containing $1.8 \%$ Cr. The main cause of so high hardness of this alloy was very strong chilling of raw castings, meaning also their poor machinability.

From the viewpoint of the possibility to obtain castings with good machinability and high hardness, the alloy should be characterised by low inclination to chilling and low stability of austenite. An example is the alloy No. 8, whose hardness of the raw casting was 210 HBS. After heat treatment, 
its hardness was over twice higher, reaching $441 \mathrm{HBW}$. This resulted from very high degree of austenite transformation (ca. 90\%) to carbon-supersaturated acicular ferrite. Concentration of carbon in this ferrite was $0.33 \pm 0.04 \% \mathrm{C}$ and its hardness was 510 to $550 \mathrm{HV} 0.1 \mathrm{~N}$.

\subsection{Abrasive-Wear Resistance Testing}

The heat-treated castings were subjected to abrasive-wear resistance tests. Results are presented in form of the wear rate coefficient, see Table 4 . The obtained results indicate occurrence of a strong relation between abrasive-wear resistance of cast iron and its chilling degree, austenite transformation degree and hardness.

Table 4. Increase of hardness and abrasive-wear indicators for heat-treated castings.

\begin{tabular}{|c|c|c|c|c|c|c|c|c|}
\hline \multirow{2}{*}{$\begin{array}{l}\text { Alloy } \\
\text { No. }\end{array}$} & \multirow{2}{*}{$\begin{array}{c}\text { Increase } \\
\text { of HBW } \\
2.5 / 187.5 \\
{[/]} \\
\end{array}$} & \multirow{2}{*}{$\begin{array}{l}\text { Wear Rate } \\
{\left[\mathrm{mg} / \mathrm{m} \cdot \mathbf{1 0}^{4}\right]}\end{array}$} & \multirow{2}{*}{$\begin{array}{l}\text { Decrease in } \\
\text { Wear Rate } \\
\text { Compared to } \\
\text { Alloy No. } 1\end{array}$} & \multicolumn{5}{|c|}{ Index of Surface Topography $[\mu \mathrm{m}]$} \\
\hline & & & & $\begin{array}{c}R_{\text {pAVR }} \\
(+/-0.02)\end{array}$ & $\begin{array}{c}R_{\text {VAVR }} \\
(+/-0.02)\end{array}$ & $\begin{array}{c}R_{\text {zAVR }} \\
(+/-0.02)\end{array}$ & $\begin{array}{c}\mathbf{R}_{\mathrm{aAVR}} \\
(+/-0.02)\end{array}$ & $\begin{array}{c}\mathrm{R}_{\mathrm{qAVR}} \\
(+/-0.02)\end{array}$ \\
\hline 1 & 154 & 2.14 & - & 5.17 & 12.19 & 17.36 & 0.87 & 1.44 \\
\hline 2 & 178 & 1.62 & -0.57 & 4.18 & 10.88 & 15.06 & 0.54 & 0.85 \\
\hline 3 & 189 & 1.52 & -0.67 & 4.19 & 10.83 & 15.02 & 0.56 & 0.87 \\
\hline 4 & 129 & 1.24 & -0.95 & 4.16 & 10.84 & 15.00 & 0.52 & 0.85 \\
\hline 5 & 112 & 0.57 & -1.62 & 4.01 & 10.02 & 14.03 & 0.48 & 0.83 \\
\hline 6 & 157 & 1.14 & -1.05 & 4.17 & 10.78 & 14.95 & 0.50 & 0.84 \\
\hline 7 & 163 & 1.05 & -1.14 & 4.14 & 10.74 & 14.88 & 0.49 & 0.83 \\
\hline 8 & 230 & 0.85 & -1.33 & 4.05 & 10.53 & 14.58 & 0.45 & 0.81 \\
\hline 9 & 205 & 1.62 & -1.29 & 4.09 & 10.68 & 14.77 & 0.44 & 0.84 \\
\hline
\end{tabular}

* A-austenite, $\mathrm{Fe}_{\mathrm{m}}$-acicular ferrite, P-pearlite. ${ }^{* *} \mathrm{Fe}_{3} \mathrm{C}$-cementite; $\mathrm{C}_{\mathrm{gr}}$-graphite; $\mathrm{Fe}_{3} \mathrm{C}+\mathrm{C}_{\mathrm{gr}}=100 \%$ high-carbon phases.

The highest wear rate, indicating the lowest abrasive-wear resistance, was demonstrated by the chromium-free alloy No. 1, free from hard spots and with the lowest austenite transformation degree. A lower wear rate of the other alloys resulted from increased chilling degree of the castings and/or increased austenite transformation degree. For this reason, among the alloys with comparable initial structure, e.g., the alloys No. 2 and 3 or the alloys No. 6 and 7, lower wear rate was demonstrated by the castings with higher concentration of chromium. The lowest wear rate was shown by the almost completely chilled alloy No. 5 containing $1.8 \%$ Cr. However, the most favourable solution, from the viewpoint of the possibility to obtain castings with good machinability and high resistance to abrasive wear, appeared the alloy No. 8 (with no hard spots and with a very high degree of austenite transformation). Its wear rate was similar to that of the alloy No. 5.

After abrasive-wear testing, the specimens were subjected to observation of their surface topography, using the SEM imaging technique. Smaller topographic diversification of the surface, indicating uniform wear, can suggest higher resistance to abrasion. Values of the indices determining surface topography were determined using a scanning electron microscope. Individual indices were determined on measuring lengths of ca. $30 \mathrm{~mm}$. The following average profile parameters were determined: the average highest peak $\left(R_{\mathrm{pAVR}}\right)$, the average lowest valley $\left(\mathrm{R}_{\mathrm{vAVR}}\right)$ and the average distance between these two values $\left(R_{z A V R}=R_{p A V R}+R_{V A V R}\right)$, the average arithmetic deviation of the profile from the average line measured along the testing section $\left(R_{A A V R}\right)$ and the average square profile deviation from the average line measured along the testing section $\left(\mathrm{R}_{\mathrm{qAVR}}\right)$. Results are given in Table 4 . The smallest topographic diversification was shown by the alloys No. 5 and No. 8. In the alloy No. 5 it was caused by almost complete chilling (ca. 95\%), but in the alloy No. 8 it resulted from very high degree of austenite transformation (ca. 90\%).

\subsection{Corrosion Resistance Testing}

In order to obtain reliable results of corrosion-resistance testing, two research methods were applied: the gravimetric method and the potentiodynamic method. 
Gravimetric measurements were continued for 24 days. The specimens were weighed (after cleaning) after the following times of exposure in 3-\% water solution of $\mathrm{NaCl}: 1,2,5,8,13,18$ and 24 days. Corrosion rates in function of time were determined according to the formula (2). Results are presented in Table 5.

Table 5. Corrosion rate $\mathrm{V}_{\mathrm{P}}$ after exposure of specimens in 3-\% solution of $\mathrm{NaCl}$.

\begin{tabular}{|c|c|c|c|c|c|c|c|c|}
\hline & \multirow{2}{*}{$\begin{array}{c}\text { Alloy } \\
\text { No. }\end{array}$} & \multicolumn{7}{|c|}{$\mathrm{V}_{\mathrm{P}}[\mathrm{mm} / \mathrm{year}]$ After Exposure for Specified Time (days) } \\
\hline & & 1 & 2 & 5 & 8 & 13 & 18 & 24 \\
\hline \multirow{2}{*}{1} & as cast & 0.55 & 0.58 & 0.56 & 0.52 & 0.48 & 0.44 & 0.39 \\
\hline & heat-treated & 0.57 & 0.59 & 0.57 & 0.55 & 0.51 & 0.45 & 0.37 \\
\hline \multirow{2}{*}{2} & as cast & 0.55 & 0.57 & 0.54 & 0.51 & 0.46 & 0.42 & 0.37 \\
\hline & heat-treated & 0.56 & 0.59 & 0.55 & 0.53 & 0.47 & 0.44 & 0.38 \\
\hline \multirow{2}{*}{3} & as cast & 0.53 & 0.55 & 0.54 & 0.50 & 0.44 & 0.42 & 0.35 \\
\hline & heat-treated & 0.53 & 0.56 & 0.55 & 0.53 & 0.44 & 0.43 & 0.37 \\
\hline \multirow{2}{*}{4} & as cast & 0.52 & 0.53 & 0.52 & 0.51 & 0.43 & 0.43 & 0.33 \\
\hline & heat-treated & 0.53 & 0.55 & 0.53 & 0.52 & 0.43 & 0.45 & 0.34 \\
\hline \multirow{2}{*}{5} & as cast & 0.49 & 0.51 & 0.50 & 0.48 & 0.44 & 0.41 & 0.30 \\
\hline & heat-treated & 0.50 & 0.52 & 0.50 & 0.48 & 0.46 & 0.42 & 0.31 \\
\hline \multirow{2}{*}{6} & as cast & 0.53 & 0.54 & 0.54 & 0.51 & 0.43 & 0.42 & 0.35 \\
\hline & heat-treated & 0.54 & 0.56 & 0.54 & 0.52 & 0.42 & 0.43 & 0.36 \\
\hline \multirow{2}{*}{7} & as cast & 0.52 & 0.53 & 0.52 & 0.50 & 0.42 & 0.41 & 0.33 \\
\hline & heat-treated & 0.53 & 0.54 & 0.53 & 0.52 & 0.41 & 0.42 & 0.34 \\
\hline \multirow{2}{*}{8} & as cast & 0.51 & 0.53 & 0.50 & 0.49 & 0.42 & 0.41 & 0.31 \\
\hline & heat-treated & 0.52 & 0.53 & 0.51 & 0.50 & 0.41 & 0.43 & 0.31 \\
\hline \multirow[b]{2}{*}{9} & as cast & 0.50 & 0.51 & 0.50 & 0.49 & 0.43 & 0.42 & 0.30 \\
\hline & heat-treated & 0.50 & 0.52 & 0.50 & 0.51 & 0.41 & 0.42 & 0.31 \\
\hline
\end{tabular}

Gravimetric examinations revealed slight differences in corrosion resistance between individual alloys. After 1 day of maintaining the specimens in the corrosive solution, corrosion rate of raw castings ranged between 0.49 and $0.55 \mathrm{~mm} /$ year. Its largest value was measured for the alloy No. 1 (containing no $\mathrm{Cr}$ ) and the smallest value-for the chilled alloy No. 5 (containing $1.8 \% \mathrm{Cr}$ ). Extension of the exposure time to 2 days resulted in higher corrosion rate of all the alloys. Maintaining the specimens for 2 to 5 days resulted in successive reduction of corrosion rate of all the alloys. This phenomenon is very favourable from the viewpoint of corrosion resistance. After 24 days of exposure, reduction of corrosion rate by ca. 30 to $40 \%$ in relation to the initial values was found in all cases.

The corrosion rate of the castings after heat treatment was slightly lower in comparison to that of raw castings. After 1 day of exposure, corrosion rate of heat-treated specimens ranged between 0.50 and $0.57 \mathrm{~mm} /$ year. Like for raw castings, its highest value was found for the Cr-free alloy No. 1, but the lowest value was found for the chilled alloy No. 5 with the highest concentration of Cr.

From the viewpoint of the possibility to obtain castings resistant to both abrasive wear and corrosion, the most favourable features were demonstrated by the alloy No. 8 containing Cr, Mo and Al. Corrosion rate of this alloy was similar to that of the most corrosion-resistant alloy No. 5. The element that most effectively increased corrosion resistance, appeared chromium.

Soaking reduces segregation of elements and can also reduce depth of corrosion pits [10], so the potentiodynamic tests were carried-out only on the heat-treated alloys that demonstrated increased resistance to abrasive wear.

During potentiodynamic tests, the specimens were subjected to polarisation after $30 \mathrm{~min}$ and after $48 \mathrm{~h}$ of their keeping in 3-\% water solution of $\mathrm{NaCl}$. Results are given in Table 6. 
Table 6. Electrochemical indicators characterising corrosion process.

\begin{tabular}{|c|c|c|c|c|c|c|c|c|}
\hline \multirow{2}{*}{ Alloy No. } & \multicolumn{2}{|c|}{$\begin{array}{c}\mathrm{E}^{\prime} \\
{[\mathrm{mV}]}\end{array}$} & \multicolumn{2}{|c|}{$\begin{array}{c}\mathrm{E}_{\mathrm{K}-\mathrm{A}} \\
{[\mathrm{mV}]}\end{array}$} & \multicolumn{2}{|c|}{$\begin{array}{c}\mathbf{i}_{\text {corr }} \\
{\left[\mu \mathrm{A} / \mathrm{cm}^{2}\right]}\end{array}$} & \multicolumn{2}{|c|}{$\begin{array}{c}R_{P} \\
{\left[\mathrm{k} \Omega \cdot \mathrm{cm}^{2}\right]}\end{array}$} \\
\hline & $30 \mathrm{~min}$ & $48 \mathrm{~h}$ & $30 \mathrm{~min}$ & $48 \mathrm{~h}$ & $30 \mathrm{~min}$ & $48 \mathrm{~h}$ & $30 \mathrm{~min}$ & $48 \mathrm{~h}$ \\
\hline 1 & -565 & -524 & -582 & -733 & 23.2 & 98.8 & 1.2 & 0.3 \\
\hline 2 & -569 & -535 & -643 & -739 & 20.1 & 92.3 & 1.2 & 0.2 \\
\hline 3 & -572 & -538 & -621 & -753 & 19.3 & 89.7 & 1.3 & 0.3 \\
\hline 4 & -581 & -544 & -618 & -751 & 18.7 & 84.5 & 1.3 & 0.3 \\
\hline 5 & -589 & -548 & -726 & -790 & 18.9 & 79.5 & 1.5 & 0.5 \\
\hline 6 & -568 & -533 & -635 & -758 & 19.8 & 94.0 & 1.3 & 0.3 \\
\hline 7 & -572 & -539 & -669 & -773 & 19.8 & 88.5 & 1.4 & 0.3 \\
\hline 8 & -597 & -556 & -659 & -790 & 18.6 & 79.5 & 1.6 & 0.5 \\
\hline 9 & -625 & -588 & -678 & -785 & 20.2 & 94.3 & 1.4 & 0.3 \\
\hline
\end{tabular}

The largest values of stationary potential $\mathrm{E}^{\prime}$, indicating elevated corrosion resistance, were found for the alloy No. 1 both after $30 \mathrm{~min}(-565 \mathrm{mV})$ and after $48 \mathrm{~h}(-524 \mathrm{mV})$, see Table 6 . This alloy showed the lowest transformation degree of its austenitic matrix, stabilised by the largest total content of $\mathrm{Ni}, \mathrm{Mn}$ and $\mathrm{Cr}\left(\mathrm{Equ}_{\mathrm{Ni}}=16.3 \%\right)$. The smallest $\mathrm{E}^{\prime}$ value was found for the alloy No. $9(-605 \mathrm{mV}$ after $30 \mathrm{~min}$ and $-558 \mathrm{mV}$ after $48 \mathrm{~h}$ ). This is the alloy with the highest austenite transformation degree. Apart from $\mathrm{Ni}, \mathrm{Mn}$ and $\mathrm{Cu}$, it contained also additions of $\mathrm{Cr}$, Mo and $\mathrm{Al}$. Longer exposure time resulted in larger $\mathrm{E}^{\prime}$ values of all the specimens. This is favourable from the viewpoint of corrosion resistance of the examined alloys.

Relatively big differences between values of the cathodic-anodic transition potential $\mathrm{E}_{\mathrm{K}-\mathrm{A}}$ (ca. 144 $\mathrm{mV}$ after 30-min exposure) for the alloys No. 1 and No. 5 indicate a diversity of electrode processes occurring on the metallic surface, see Table 6 and Figure 3. This is related to the phase composition diversity of the examined alloys. Longer time of exposure in the corrosive solution resulted in smaller differences between $\mathrm{E}_{\mathrm{K}-\mathrm{A}}$ values of individual alloys.

Values of corrosion current density $i_{\text {corr }}$ and of polarisation resistance $R_{p}$ showed the inversely proportional relation, see Table 6 . Smaller $i_{\text {corr }}$ values and larger $R_{p}$ values often indicate increased corrosion resistance. However, the obtained results do not indicate radical differences of these values between individual alloys (Table 6 and Figure 3). After 30-min exposure, the $\mathrm{i}_{\text {corr }}$ values ranged from 18.6 to $23.2 \mu \mathrm{A} / \mathrm{cm}^{2}$, but the $R_{p}$ values ranged within 1.2 to $1.6 \mathrm{k} \Omega \cdot \mathrm{cm}^{2}$. In turn, lower exposure time resulted in slightly increased $i_{\text {corr }}$ values $\left(79.5\right.$ to $\left.98.8 \mu \mathrm{A} / \mathrm{cm}^{2}\right)$ and decreased $R_{p}$ values $(0.2$ to $\left.0.5 \mathrm{k} \Omega \cdot \mathrm{cm}^{2}\right)$.

The results of potentiodynamic tests did not show radical differences between the corrosion resistances of individual alloys. Longer exposure time of specimens did not cause significant changes of their corrosion resistance, either. This is why additional observations of surface topography of the specimens after potentiodynamic testing and after 48-h exposure in the corrosive solution were carried out. Results are given in Table 7. 


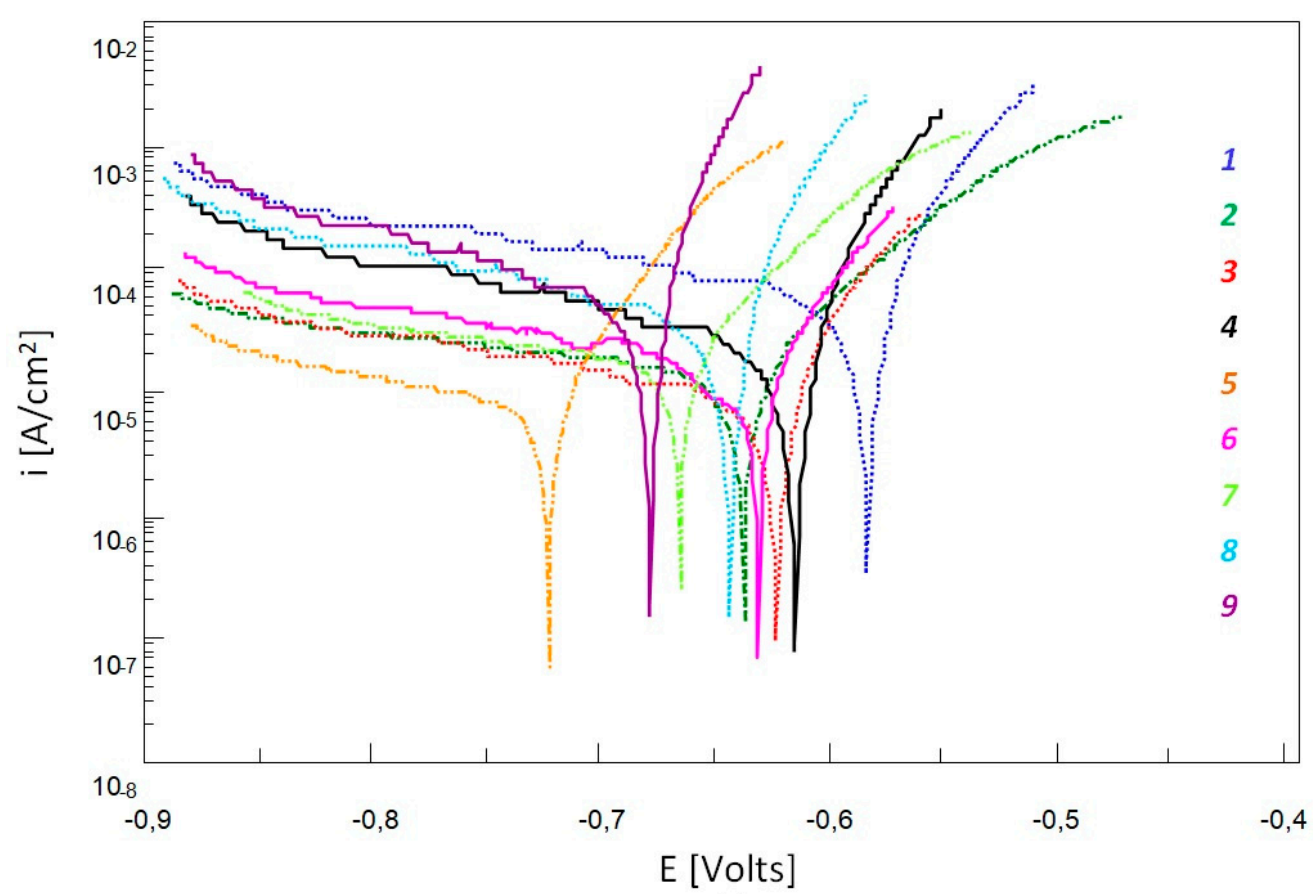

(a)

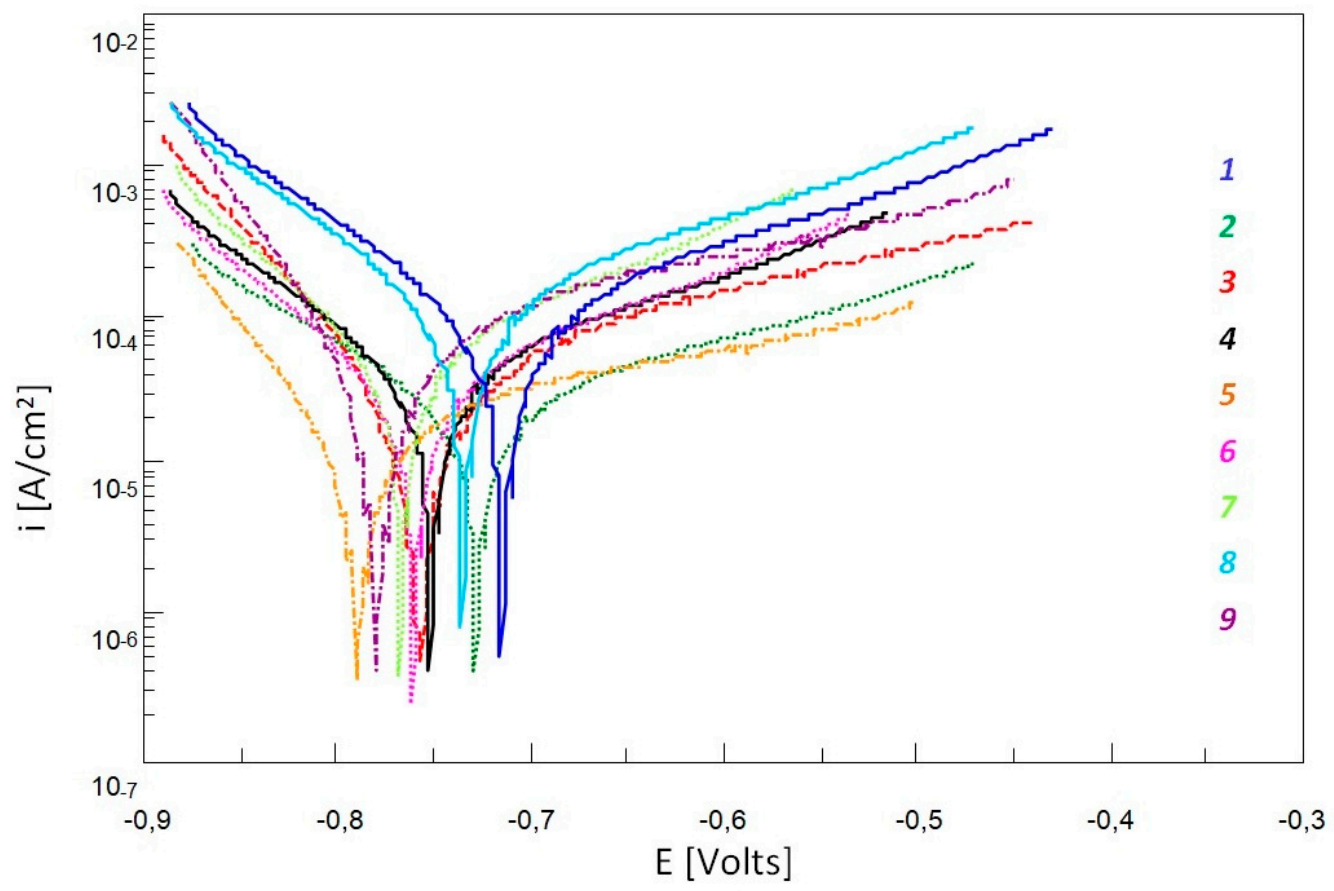

(b)

Figure 3. Polarisation curve for the alloys No. 1 to No. 9 after 30-min (a) and 48-h (b) exposure in 3-\% aqueous solution of $\mathrm{NaCl}$. 
Table 7. Indicators describing surface topography of specimens after potentiodynamic tests (after 48-h exposure in 3-\% aqueous solution of $\mathrm{NaCl}$ ).

\begin{tabular}{|c|c|c|c|c|c|c|c|}
\hline \multirow{2}{*}{$\begin{array}{l}\text { Alloy } \\
\text { No. }\end{array}$} & \multirow{2}{*}{$\begin{array}{c}\mathrm{Equ}_{\mathrm{Ni}} \\
{[w \mathrm{w} \%]}\end{array}$} & \multirow{2}{*}{$\begin{array}{c}\mathrm{Cr} \\
{[w \mathrm{t} \%]}\end{array}$} & \multirow{2}{*}{$\begin{array}{c}\text { Mo } \\
{[w t \%]}\end{array}$} & \multirow{2}{*}{$\begin{array}{c}\text { Al } \\
\text { [wt \%] }\end{array}$} & \multicolumn{3}{|c|}{ Surface Topography Index $[\mu \mathrm{m}]$} \\
\hline & & & & & $\begin{array}{c}R_{\text {pAVR }} \\
(+/-0.03)\end{array}$ & $\begin{array}{c}\mathbf{R}_{\text {VAVR }} \\
(+/-0.03)\end{array}$ & $\begin{array}{c}\mathrm{R}_{\text {zAVR }} \\
(+/-0.03)\end{array}$ \\
\hline 1 & 16.3 & - & - & - & 5.01 & 34.64 & 39.65 \\
\hline 2 & 16.1 & 0.4 & - & - & 4.98 & 33.35 & 38.33 \\
\hline 3 & 16.0 & 0.7 & - & - & 4.85 & 32.21 & 37.06 \\
\hline 4 & 16.1 & 0.9 & - & 0.4 & 4.77 & 28.25 & 33.02 \\
\hline 5 & 16.0 & 1.8 & - & 0.4 & 4.73 & 21.14 & 25.87 \\
\hline 6 & 16.2 & 0.7 & 0.2 & - & 4.86 & 24.17 & 29.03 \\
\hline 7 & 16.1 & 1.0 & 0.2 & - & 4.72 & 22.14 & 28.86 \\
\hline 8 & 16.0 & 0.7 & 0.5 & 0.4 & 4.61 & 19.08 & 23.75 \\
\hline 9 & 16.0 & 1.1 & 0.5 & 0.4 & 4.58 & 19.14 & 23.66 \\
\hline
\end{tabular}

As for the differences between individual samples, in the alloy No. 1 with the largest $\mathrm{Equ}_{\mathrm{Ni}}$ value, a small number of relatively deep pits were found. Introduction of $\mathrm{Cr}$, also $\mathrm{Mo}$ (that reduces stability of austenitic matrix) resulted in successive decrease of depth of the pits accompanied by an increase of their number. This effect is favourable from the viewpoint of corrosion resistance. The largest number of pits with the smallest depth was found in the alloys with the high total content of $\mathrm{Cr}$, Mo and $\mathrm{Al}$, the highest degree of austenite transformation and fragmentation of eutectic colonies. In all the alloys, corrosion damages were located mainly in vicinity of eutectic colonies and of phase boundaries, see Figures 4 and 5. This was due to differences in electrochemical potentials between individual phases.

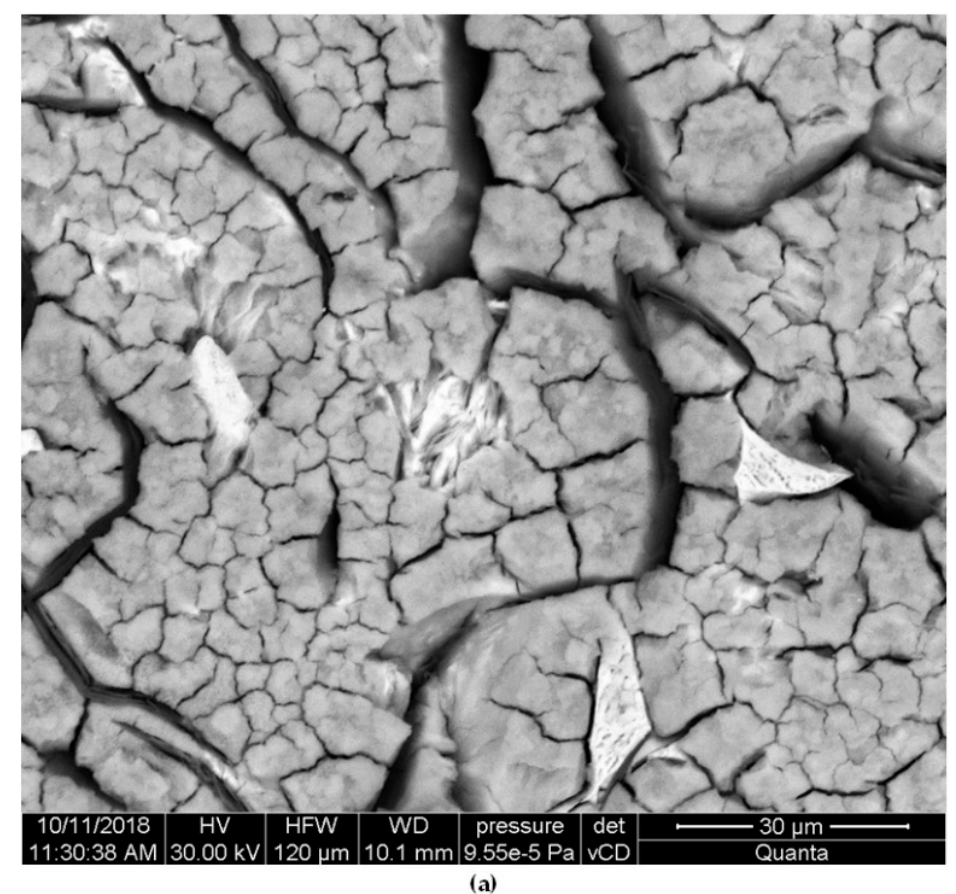

Figure 4. Cont. 


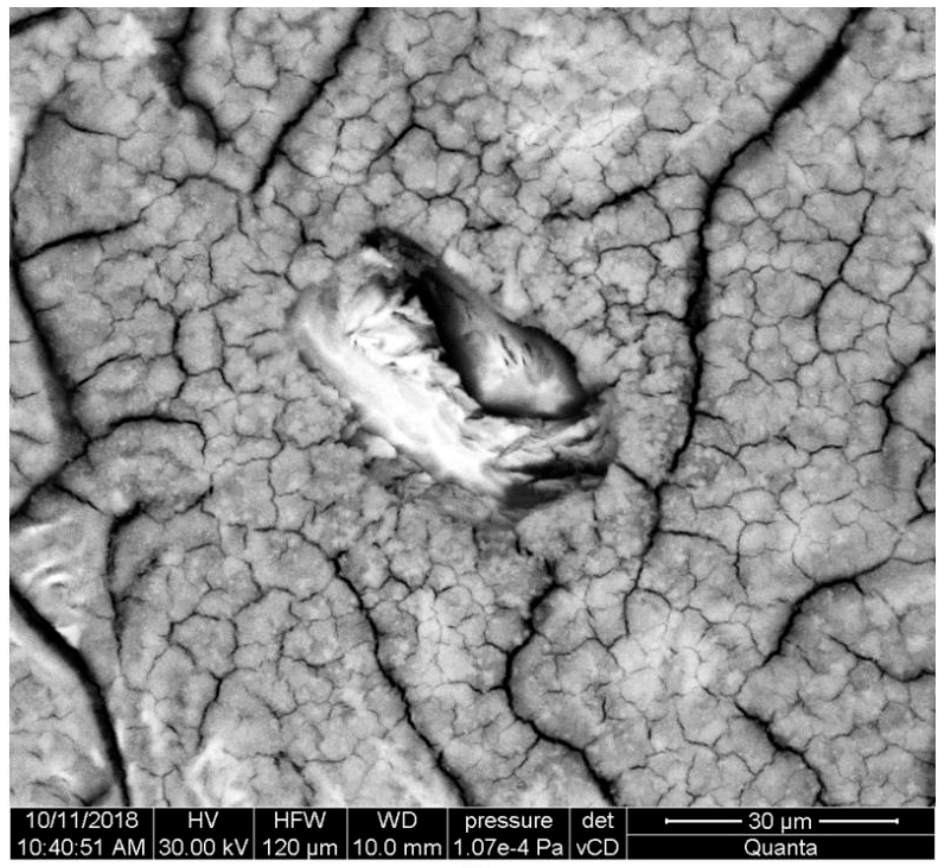

(b)

Figure 4. Face surfaces of specimens after potentiodynamic tests, exposed previously for $48 \mathrm{~h}$ in 3-\% solution of $\mathrm{NaCl}$ : alloy No. 1 (a) and alloy No. 8 (b). Unetched.

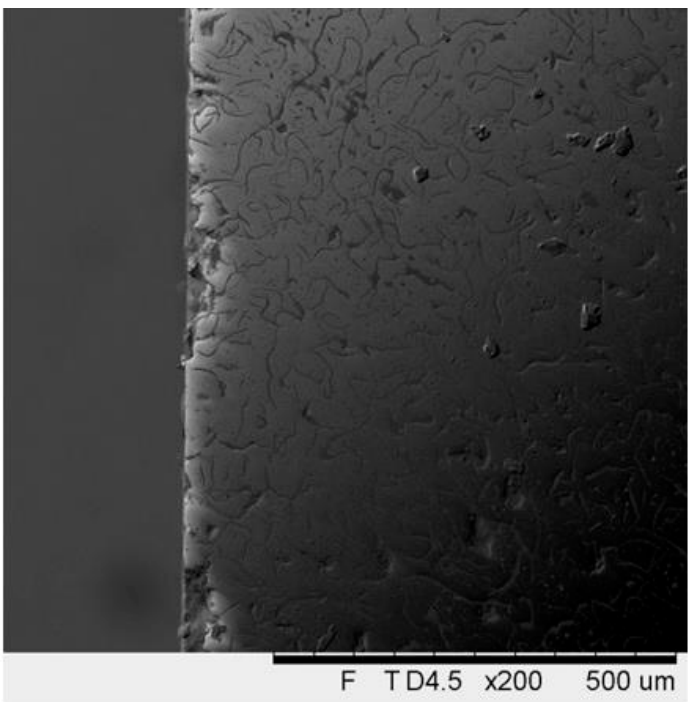

(a)

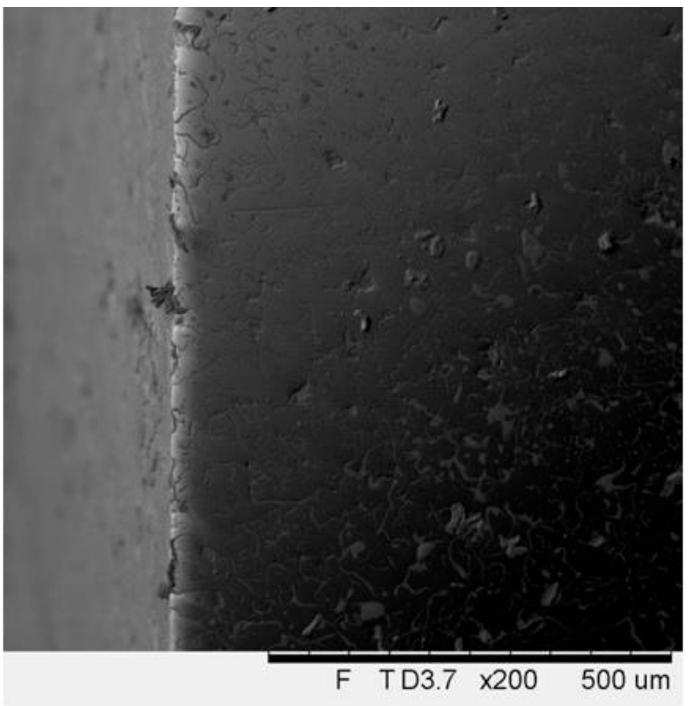

(b)

Figure 5. Cross-section surfaces of specimens after potentiodynamic tests, exposed previously for $48 \mathrm{~h}$ in 3-\% solution of NaCl: alloy No. 1 (a) and alloy No. 8 (b). Unetched.

The mechanism of corrosion damage was typical for pitting corrosion. He was discussed on example of alloy No. 1, due to the smallest degree of austenite conversion, and thus the readability of analysis. After 30 min exposure of samples in corrosive solution, the greatest corrosion damage was observed primarily near graphite flakes (Figure 6a) This was due to significant differences of electrochemical potentials between graphite $(+0.372 \mathrm{~V})$ and the cast iron matrix $(-0.776 \mathrm{~V})[26,27]$. As a result of a large potential difference, which was about $1 \mathrm{~V}$, micro-cells were formed, increasing the corrosion rate. After the samples were stored in a corrosive solution for $48 \mathrm{~h}$, deepening of pits near the graphite was found. In addition, corrosion damage appeared in the matrix, mainly at the boundaries of austenite grains (Figure 6b). 


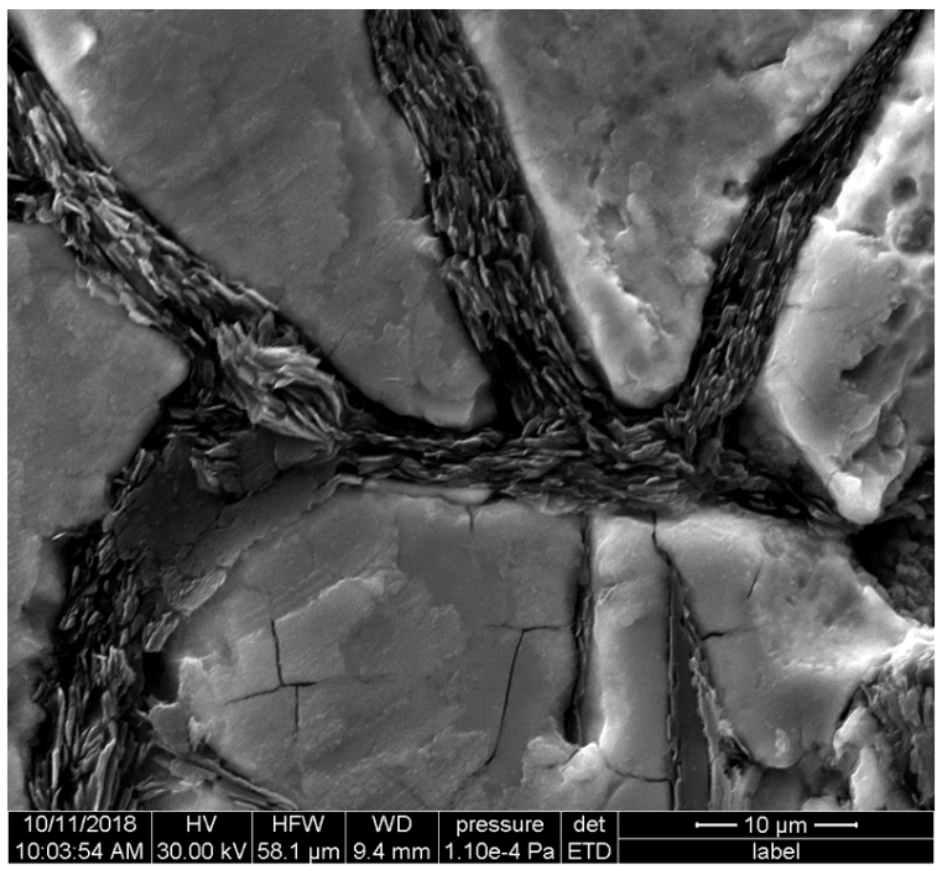

(a)

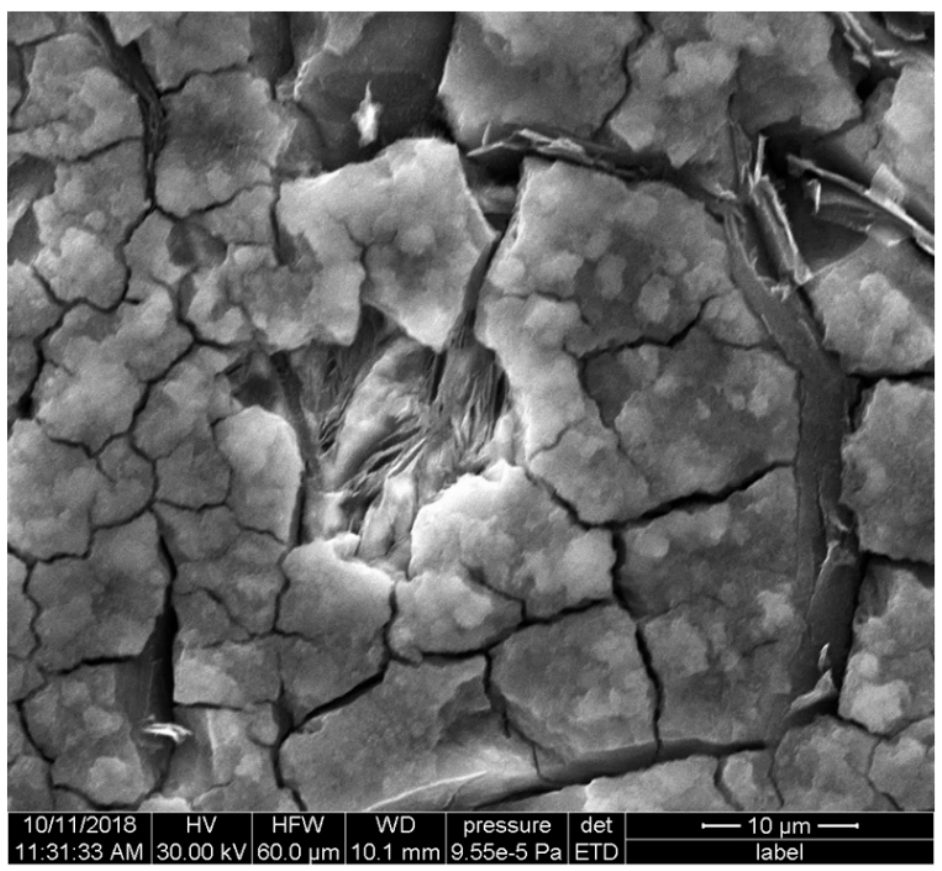

(b)

Figure 6. Face surfaces of specimens alloy No. 1 after potentiodynamic tests, exposed previously in 3-\% solution of $\mathrm{NaCl}$ for: $30 \mathrm{~min}(\mathbf{a})$ and $48 \mathrm{~h}(\mathbf{b})$. Unetched.

\section{Conclusions}

The matrix structure of all raw castings was composed exclusively of austenite. The accepted concentration ranges of $\mathrm{Cr}$, Mo and $\mathrm{Al}$ did not cause the phase transformations that occur in the case of too low thermodynamic stability of austenite. However, it was found that hardness of austenite increased with increasing concentrations of $\mathrm{Cr}$ and Mo.

As the contents of mainly $\mathrm{Cr}$ and Mo increased, the quantity and size of graphite particles decreased and a tendency to their interdendritic arrangement increased. These elements resulted in 
higher susceptibility of the alloy to chilling (creating hard spots). This resulted in a clearly higher hardness of raw castings. An addition of $0.4 \% \mathrm{Al}$ partially restricted this tendency.

Heat treatment led to partial austenite transformation to carbon-supersaturated, hard acicular ferrite in all castings. The transformation degree increased with increasing concentrations of $\mathrm{Cr}$ and $\mathrm{Mo}$, which is an evidence that both elements reduce the thermodynamic stability of the austenitic matrix.

The largest increments of hardness and abrasive-wear resistance, caused by heat treatment, occurred in the castings with the highest degree of austenite transformation, that is in the castings with the largest content of $\mathrm{Cr}$ and $\mathrm{Mo}$, and with an addition of $0.4 \% \mathrm{Al}$.

At the same time, introduction of $\mathrm{Cr}$ and Mo to cast iron (elements with relatively high electrochemical potential) resulted in increased corrosion resistance. Increasing concentrations of $\mathrm{Cr}$ and $\mathrm{Mo}$ (mainly $\mathrm{Cr}$ ) resulted in lower corrosion rates of raw castings because as the total content of both elements increased, the quantity and size of graphite flakes decreased (usually damages were found near them), the tendency to interdendritic distribution and fragmentation of eutectic colonies increased. Heat treatment of the castings resulted in unimportant, in comparison to increased abrasion resistance, reduction of the corrosion resistance in relation to raw castings. Introduction of $\mathrm{Cr}$ and $\mathrm{Mo}$, the elements reducing the stability of the austenitic matrix, resulted in a successive reduction of the depth of corrosion pits, accompanied by an increase in their number. From the viewpoint of corrosion resistance, this phenomenon is desirable.

Author Contributions: Conceptualization, D.M. and A.J.; Formal analysis, D.M., B.S.; Investigation, D.M., B.S and J.C.; Methodology, D.M.; Supervision, A.J.; Writing—original draft, D.M.; Writing—review \& editing, A.J. and J.C.

Funding: This research received no external funding.

Conflicts of Interest: The authors declare no conflict of interest.

\section{References}

1. Ni-Resist/Austenitic Cast Iron (EN-GJLA/EN-GJSA). Available online: https://www.esterer-giesserei.de/ fileadmin/user_files/pdf/Ni-Resist_GJSA_.pdf (accessed on 24 October 2019).

2. Janus, A. Forming of Castings Structure of Austenitic Cast Iron $\mathrm{Ni}-\mathrm{Mn}-\mathrm{Cu}$; Editorial Office of Wroclaw University of Technology: Wroclaw, Poland, 2013.

3. Janus, A.; Granat, K. Abrasion Resistant Austenitic-Bainitic Cast Iron; Report of Institute of Machine Engineering and Automation of Wroclaw University of Technology; SPR 28; Institute of Machine Engineering and Automation of Wroclaw University of Technology: Wroclaw, Poland, 2005.

4. Medyński, D.; Janus, A. Effect of Chemical composition on structure and corrosion resistance of $\mathrm{Ni}-\mathrm{Mn}-\mathrm{Cu}$ cast iron. Arch. Foundry Eng. 2016, 16, 59-62. [CrossRef]

5. Medyński, D.; Janus, A. Effect of austenite transformation on abrasive wear and corrosion resistance of spheroidal Ni-Mn-Cu cast iron. Arch. Foundry Eng. 2016, 16, 63-66. [CrossRef]

6. Medyński, D.; Janus, A.; Zaborski, S. Effect of heat-treatment parameters of cast iron GJS-X350NiMnCu7-3-2 on its structure and mechanical properties. Arch. Foundry Eng. 2017, 17, 121-126. [CrossRef]

7. Medyński, D.; Janus, A. Effect of heat treatment parameters on abrasive wear and corrosion resistance of austenitic nodular cast iron Ni-Mn-Cu. Arch. Civ. Mech. Eng. 2018, 18, 515-521. [CrossRef]

8. Medyński, D.; Janus, A. Abrasive-wear resistance of austenitic cast iron. Arch. Foundry Eng. 2018, 18, 43-48.

9. Medyński, D.; Janus, A. Effect of nickel equivalent on structure and corrosion resistance of nodular cast iron Ni-Mn-Cu. Arch. Foundry Eng. 2015, 15, 69-74.

10. Medyński, D.; Janus, A.; Chęcmanowski, J. Effect of annealing on nature of corrosion damages of medium-nickel austenitic cast iron. Arch. Foundry Eng. 2017, 17, 85-90. [CrossRef]

11. Gumienny, G. Carbidic bainitic and ausferritic ductile cast iron. Arch. Metall. Mater. 2013, 58, $1053-1058$. [CrossRef]

12. Wilk-Kołodziejczyk, D.; Regulski, K.; Gumienny, G. Comparative analysis of the properties of the nodular cast iron with carbides and the austempered ductile iron with use of the machine learning and the support vector machine. Int. J. Adv. Manuf. Technol. 2016, 87, 1077-1093. [CrossRef] 
13. Zhang, J.; Zhang, N.; Zhang, M.; Liantao, L.; Zeng, D. Microstructure and mechanical properties of austempered ductile iron with different strength grades. Mater. Lett. 2014, 119, 47-50. [CrossRef]

14. Fatahalla, N.; Hussein, O. Microstructure, mechanical properties, toughness, wear characteristics and fracture phenomena of austenitized and austempered low-alloyed ductile iron. Open Access Libr. J. 2015, 2, 1-16.

15. Panneerselvama, S.; Putatundaa, S.K.; Gundlachb, R.; Boileauc, J. Influence of intercritical austempering on the microstructure and mechanical properties of austempered ductile cast iron (ADI). Mater. Sci. Eng. A 2017, 694, 72-80. [CrossRef]

16. Junjun, C.; Liqing, C. Microstructure and abrasive wear resistance of an alloyed ductile iron subjected to deep cryogenic and austempering treatments. J. Mater. Sci. Technol. 2017, 33, 1549-1554.

17. Konca, E.; Tur, K.; Koç, E. Effects of Alloying Elements (Mo, Ni and Cu) on the austemperability of GGG-60 ductile cast iron. Metals 2017, 7, 320. [CrossRef]

18. Zhou, M.; Xu, G.; Wang, L.; He, B. Effects of austenitization temperature and compressive stress during bainitic transformation on the stability of retained austenite. Trans. Indian Inst. Met. 2017, 70, 1447-1453. [CrossRef]

19. Sarkar, T.; Bose, P.K.; Sutradhar, G. Mechanical and tribological characteristics of copper alloyed austempered gray cast iron (AGI). Mater. Today Proc. 2018, 5, 3664-3673. [CrossRef]

20. Sellamuthu, P.; Harris Samuel, D.G.; Dinakaran, D.; Premkumar, V.P.; Li, Z.; Seetharaman, S. Influence of austempering temperature on microstructure, mechanical and wear properties and energy consumption. Metals 2018, 8, 53. [CrossRef]

21. Jalava, K.; Soivio, K.; Laine, J.; Orkas, J. Elevated temperature thermal conductivities of some as-cast and austempered cast irons. Mater. Sci. Technol. 2018, 34, 327-333. [CrossRef]

22. Pujara, J.; Kothari, K.; Gohil, A. An investigation of material removal rate and kerf on WEDM through grey relational analysis. J. Mech. Eng. Sci. 2018, 12, 3633-3644. [CrossRef]

23. Wen, F.; Zhao, J.; Zheng, D.; He, K.; Ye, W.; Qu, S.; Shangguan, J. The role of bainite in wear and friction behavior of austempered ductile iron. Materials 2019, 12, 767. [CrossRef]

24. Duenas, J.R.; Hormaza, W.; Castro Güiza, G.M. Abrasion resistance and toughness of a ductile iron produced by two molding processes with a short austempering. J. Mater. Res. Technol. 2019, 8, 2605-2612. [CrossRef]

25. Nofal, A.A.; Amal, S.I.; Ghanem, W.A.; Hussein, W.A.; El-dabaa, N.K. The effect of austempering heat treatments on the microstructure and corrosion behavior of cast iron in $3.5 \%$ sodium chloride soliton. Int. J. Adv. Res. 2019, 7, 1551-1558. [CrossRef]

26. Podrzucki, C. Cast Iron: Structure, Properties and Application; T 1/2; ZG STOP: Krakow, Poland, 1999.

27. Bala, H. Corrosion of Materials-Theory and Practice; Editorial Office of Process Engineering, Materials and Applied Physics of Czestochowa University of Technology: Czestochowa, Poland, 2002.

28. Hryniewicz, T. Electrochemistry for Surface Engineering; Editorial Office of Koszalin University of Technology: Koszalin, Poland, 2005.

29. Hryniewicz, T.; Rokosz, K. Theoretical Basis and Practical Aspects of Corrosion; Editorial Office of Koszalin University of Technology: Koszalin, Poland, 2010.

30. Raczka, J.S.; Tabor, A.; Kowalski, A. Resistance of austenitic-bainitic nodular cast iron to corrosive action of sulphuric, nitric and hydrochloric acids. Solidif. Met. Alloys 2000, 2, 527-535.

31. Cheng-Hsun, H.; Ming-Li, C. Corrosion behavior of nickel alloyed and austempered ductile iron in $3.5 \%$ sodium chloride. Corros. Sci. 2010, 52, 2945-2949.

32. Chung-Kwei, L.; Cheng-Hsun, H.; Yin-Hwa, C.; Keng-Liang, O.; Sheng-Long, L. A study on the corrosion and erosion behavior of electroless nickel and TiAlN/ZrN duplex coatings on ductile iron. Appl. Surf. Sci. 2015, 324, 13-19.

33. Song, Y.; Jiang, G.; Chen, Y.; Zhao, P.; Tian, Y. Effects of chloride ions on corrosion of ductile iron and carbon steel in soil environments. Sci. Rep. 2017, 7, 6865. [CrossRef]

(C) 2019 by the authors. Licensee MDPI, Basel, Switzerland. This article is an open access article distributed under the terms and conditions of the Creative Commons Attribution (CC BY) license (http://creativecommons.org/licenses/by/4.0/). 